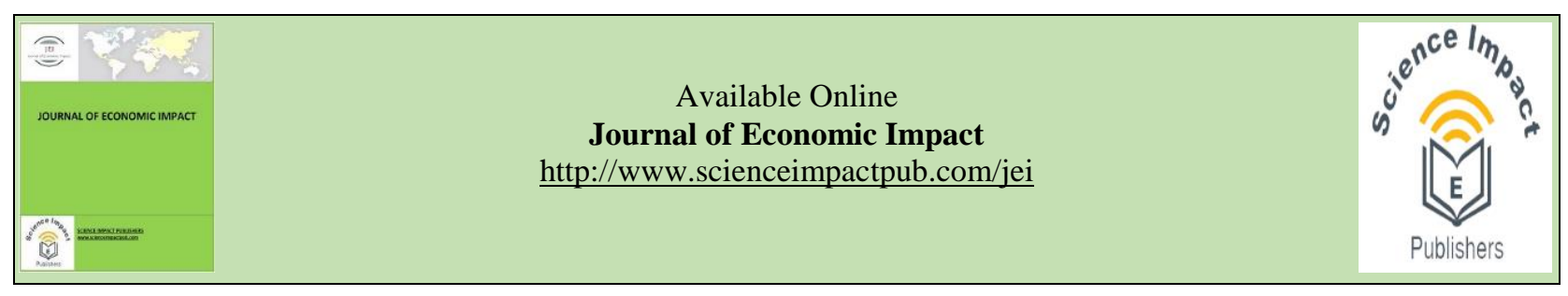

\title{
ECONOMIC GROWTH, ENERGY AND ENVIRONMENTAL DEGRADATION NEXUS: A CASE STUDY IN PAKISTAN
}

\author{
Rabia Nawaz ${ }^{\mathrm{a}}$, Muhammad Azam ${ }^{\mathrm{a}, *}$, Hanzala Zulfiqar ${ }^{\mathrm{b}}$ \\ a Department of Economics, University of Lahore, Sargodha, Pakistan \\ b Pakistan Institute of Development Economics, Islamabad
}

\section{HIGHLIGHTS}

- The study has concluded that there is an evidence of inverted U shaped EKC in Pakistan and this relationship varies with different types of pollutants and geographical regions.

- Initially, income has a positive relationship with $\mathrm{CO}_{2}$ emission but after the turning point, both have a negative relationship.

- The per capita real income has a positive sign but the square of per capita real income has a negative sign which proves that after the turning point $\mathrm{CO}_{2}$ emission will decrease with the increase of income.

- The relation between $\mathrm{CO}_{2}$ and per capita income is positive, which has strong evidence of reversed $\mathrm{U}$ form environmental Kuznets curve in Pakistan.

- For the improvement and control of environment quality, energy sources should be carbon-free.

ABSTRACT
This study estimated the growth, energy and environmental degradation nexus in Pakistan by using time series
data. The data have been taken from the World Bank for the year 1971 to 2011 . The data analysis was done by
using the approach of co-integration (ARDL bound test) to confirm the effective long-term positive relationship
among carbon dioxide emissions, per capita income growth and the per capita income gap to monitor the trend of
the Environmental Kuznets Curve in Pakistan. The results of the study showed that there is no evidence of a serial
correlation between the variables in the discussion, but they have a long-term association. Energy usage and per
capita real income, has a positive relationship with $\mathrm{CO}_{2}$ emissions. The study has concluded that there is an
evidence of inverted U shaped EKC in Pakistan and this relationship varies with different types of pollutants and
geographical regions. Initially, income has a positive relationship with $\mathrm{CO}_{2}$ emission but after the turning point,
both have a negative relationship.

Keywords: Environmental Kuznets Curve; $\mathrm{CO}_{2}$ emission; environmental degradation; Pakistan.

Received: March 09, 2020; Accepted: March 30, 2020; Published: April 06, 2020.

* Correspondence: Department of Economics, University of Lahore, Sargodha Campus, Sargodha, Pakistan

Email: muhammad.azam@econ.uol.edu.pk

\section{Introduction}

Over the past few decades, the concept of environmental quality is nourishing rapidly all over the world. Degradation of environmental is the destruction of environmental quality due to the usage of natural resources or elements like air, water, soil and destruction of the ecosystem and other factors like wildlife. It can also define as the change and disturbance of the environment which is not desirable by any economy. All over the world the climatic changes, degradation of land and water scarcity are the growing and increasing issues in the 20th century that need to be urgently addressed or notified. If the running world wants to fulfill the goals set out in the 2030 agenda for sustainable development then there is a need to resolve such common issues by their combine efforts. Sharif and Raza (2016) was noticed that policies in which the government requires to assign larger share to environmental safeguard strategies and energy saving modules in the planning, like boosting energy saving framework and creating a chain of increasing indicators of environmental protection strategies and energy saving attempts. AlMulali et al. (2015) showed that many researchers applying various econometric methodologies have extensively analyzed environmental degradation; taking into account multiple countries and regions over the years. Larger numbers of studies worked on 
$\mathrm{CO}_{2}$ pollution as an environmental degradation measure.

Due to such environmental problems, the developing economies suffer from water pollution, soil erosion and loss of biodiversity according to the international panel of climate change. Field et al. (2012) and Groot et al. (2002) explained that the issue also threatens to make some land areas less productive for the use of agriculture. While also creating changes in the temperature of the ocean that is a great threat for coral reefs and fish population on which the life of human beings mostly depends. In 2013, $\mathrm{CO}_{2}$ is ascertained for around $82 \%$ of all U.S discharged gas outflow from the after effect of human exercises. Essentially $\mathrm{CO}_{2}$ is actually accessible in the environment as a component of earth however human exercises additionally changing the normal carbon cycle by including $\mathrm{CO}_{2}$ in the climate by their exercises. (EPA, 2013) The main source of human activities that increase $\mathrm{CO}_{2}$ in the atmosphere is the combustion of fossil fuels for energy and the use of transportation. The fossil fuels are coal, natural gas, and burning of oil. (EPA, 2013)

Several academic papers have been studied, some have used the study of time series while others have used panel data analysis to analyse the effect of explanatory variables on dependent variable. Some paper supports the existence of the environmental Kuznets curve but some concluded that not all the pollutants have the same relationship to prove the inverted $U$ shape curve. According to the data of different pollutants and regions there had different results for the shape of EKC such as inverted $U$ shape, formal $\mathrm{U}$ shape, $\mathrm{N}$ shape, and some countries follow the $\mathrm{S}$ shape.

\section{Income Growth and Environmental Quality: A Theoretical Perspective}

Environmental quality is a combination of properties and features of the environment, moreover global or native, as they impose on human lives and other organisms also. $\mathrm{CO}_{2}$ emission is the amount of gas released by burning woods, waste material, oil, coal, gas, and the use of energy.

In the last few decades, $\mathrm{CO}_{2}$ emission is considered as the main pollutant which is produced due to the development activities. In developing countries, much attention has been paid to the relationship of $\mathrm{CO}_{2}$ with financial growth, revenue rates, energy usage, and trade ease of access. All these activities are responsible for economic development but they also are responsible for environmental degradation. So the relationship between these factors and environmental pollution like $\mathrm{CO}_{2}$ is rapidly growing in the different developing countries. They also use to prove the existence of the environmental Kuznets curve. (EPA, 2013)
The advancement of technology provides energy generation, sufficient food production, and better economic growth but on the other hand, it also generates bad environmental impacts. The different governments of different countries have adopted many measures to fight against the Global Financial Crisis. The former literature appears to suggest that urbanization is one of the main contributing factors to the increasing levels of $\mathrm{CO}_{2}$ emissions. Therefore, there is a great demand for some rational policies that should be implemented to promote the minimum carbon consuming actions of urban residents and hold the luxury consumption of energy-intensive products.

Income Growth and Environmental Quality: An Empirical Perspective

Sharif and Raza (2016) explored the nexus of $\mathrm{CO}_{2}$ emission-urbanization-growth in Pakistan by using data from the years 1972 to 2013. The research used the co-integration approach (ARDL bounding test) to support the long-term positive legal relationship between $\mathrm{CO}_{2}$ emissions and urbanization. The results of VDM demonstrated the uni-directional causality between $\mathrm{CO}_{2}$ emission and urbanization. The study also suggested the theoretical framework for energy saving and environmental protection.

The causes of environmental degradation in the MENA region were elaborated by Al-Mulali and Ozturk (2015). The study findings discussed the cointegration of ecological footprints, energy use, urbanization, trade accessibility, economic growth, and political stability. Shahbaz et al. (2013) analyzed the usage of energy and environmental Kuznets curve during the period of 1980-2010 in Romania. Through applying the ARDL bound process, the analysis investigated the long-term relationship between economic growth, energy usage, and $\mathrm{CO}_{2}$ emissions. Ozturk and Acaravci (2013) explained the causal relationship among Turkey's financial development, country production, and energy use and carbon dioxide surges.

Pao and Tsai (2010) clarified the effect on environmental degradation of both economic growth and financial development. The study used the panel data from BRIC countries over the period 1980-2007 except Russia. The study result proves the existence of the Kuznets curve for the setting. As a consequence, the high bidirectional causality between $\mathrm{CO}_{2}$ and FDI and unidirectional causality between production and FDI were also indicated. Everett et al. (2010) focused on economic growth and environmental changes. The natural environment provides resources and raw material, water purification and managing flood risks. $\mathrm{CO}_{2}$ emission is one of the results of technology that increases the temperature of the world by almost 20 degrees. This paper uses the EKC hypothesis to 
explain the connection between economic growth and environmental quality.

Jalil and Mahmud (2009) explained the environmental effects of production, energy use, and financial development in China. The results demonstrated the presence of natural Kuznets bend in China. Tamazian et al. (2009) focused the BRIC countries on the evidence of EKC. It also presents the important econometric weaknesses in the vast numbers of studies explained the environmental degradation and economic development. Akbostanc1 et al. (2009) checked the relationship between income and environmental quality in the country of Turkey and explained the results of an increasing correlation between $\mathrm{CO}_{2}$ and income. The panel data result suggested a relationship between the emission of $\mathrm{SO}_{2}$ and PM10 in N-shape. Harris and Roach (2008) analyzed the existence of the EKC using the Ecological Footprint (EF) definition. The ecological footprint explained how it could be possible that the environmental disturbance associated with human activities. According to Burke (2008), the environmental Kuznets curve may be generated by adopting low $\mathrm{CO}_{2}$ emission technologies as the result of a higher income level.

Hung and Shaw (2004) worked on the relationship between energy usage and $\mathrm{CO}_{2}$ emission by using the VAR model for the panel data. The result of the study concluded that only in the group of highincome level countries, CLPD moves the use of energy negatively and such countries get environmental betterment as the conclusion of more efficient energy usage and try to decrease in $\mathrm{CO}_{2}$ emission. But in the case of countries which have upper-middle-income level, energy efficiency decline and emission of $\mathrm{CO}_{2}$ increases. Shen (2006) analyzed the presence of EKC in the nation of China and utilized the statistical information of Chinese different provinces from the year 1993 to 2002 using the time series data of per capita income and per capita pollutant elements. Stern (2004) inspected the relationship between PCI and emission and demonstrated the modified U-formed Kuznets bends. Ghafoor et al. (2002) focused on the problems of the environmental pollution by using the time series data taken from the World Bank, IMF and Asian development bank. According to them, every country was trying to increase economic growth to attain a higher level of living standard but as a result, it creates environmental problems and reduction of natural resources.

Yang et al. (2012) explored the relationship among environmental pollutant elements and economic growth in the province of Zhejiang. Data from 1981-2006 have been used by the study and employing the method of Johansen cointegration test and granger causality test. Jobert et al. (2012) used the
Bayesian Shrinkage produced for testing the hypothesis of EKC that used the first time in the literature. The result of the study suggested that the EKC hypothesis is rejected for 49 countries out of 55 . Selden and Song (1994) used the curse-national penal data for the existence of an environmental Kuznets curve. The research utilized the four main air contaminants, such as sulfur dioxide, suspended particulate matter, carbon monoxide, and nitrogen. The result of the study that per capita emission of all these contaminants exhibits an inverted-U relationship with GDP and emission will decrease in the case of the long run.

The paper has been comprised to formulate a theoretical framework emphasizing the link between the variables of income growth and quality of the environment, formulate the theoretical recommendation of policy implementation and empirically evaluate the impact of factors influencing $\mathrm{CO}_{2}$ emission and existence of EKC in Pakistan.

\section{Methodology}

The purpose of this section is to discuss econometric methods for testing the hypotheses of a theoretical framework as mentioned in the previous chapter for examining the impact of income on the environment.

\section{The Theoretical Framework}

The study focuses on evaluating the impact of income growth and environmental quality. Hence the dependent variable is pollutant variable $\mathrm{CO}_{2}$. The study evaluates the relationship with the help of the EKC theory. In the general form of EKC describes a relationship among the variables of income growth and quality of the environment. Empirically specifications the model is specified as follows;

$$
E=f\left(y, y_{2}, z\right) \ldots \ldots(1)
$$

In this model $\mathrm{E}$ expresses the element of an environmental indicator of Pakistan, $\mathrm{Y}$ indicates the income, $\mathrm{Y}^{2}$ used to describe the trend of environmental Kuznets curve and $\mathrm{Z}$ explains the other explanatory variables which are assumed to affect the environmental quality. This study focused on evaluating the influence of income growth on the quality of the environment. The dependent variable, therefore, is carbon dioxide emission $\mathrm{CO}_{2}$. For the empirical specifications, the model is specified as;

$$
\Delta C O_{2 t}=\alpha_{0}+\alpha_{1} Y_{t}+\alpha_{2} Y_{t}^{2}+\alpha_{3} Z_{t}+u_{t} \cdots
$$

In the above equation $\mathrm{CO}_{2 \mathrm{t}}$ indicates carbon dioxide emission indicator taken as a dependent variable in the form of metric $\mathrm{kg}$ per capita. On the right side of the equation the $\mathrm{Y}$ depicts an explanatory variables that include GDP per capita growth, which include the GDP per capita growth, GINI index, public 
spending on education, health expenditure per capita and data on natural capital in the form of fuel exports (as percentage of merchandise exports). The $\mathrm{Z}_{\mathrm{t}}$ depicts a set of explanatory variables that include EC energy consumption and is taken as an independent variable, which consists of fuel type means liquid fuels, coal, and natural gas, renewable and nuclear resources but on the other hand, the sector means industrial sector, transportation and electricity department and trade openness taken as \% of GDP.

$\mathrm{Z}$ explains the other explanatory variables which are assumed as the control variable of the model but they affect the environmental quality. Based on theoretical model it gives prediction about the negative impact of income growth on environmental quality. Thus, expected sign of $\alpha 1>$ 0 is positive sign but $\alpha 2<0$ is negative given as in the equation 2 .

\section{Econometric Model of Literature}

The empirical model of this study has been estimated with time series data method and ARDL approach in existing EKC theory. Empirical model of this paper specifies the long term relationship among per capita use of energy, per capita income and openness of country's trade with the combination of carbon dioxide emission in the country of Pakistan. The model may be expressed as

$$
\begin{gathered}
C O_{2 t}=\beta_{1 t}+\beta_{2} E c_{t}+\beta_{3} Y_{t}+B_{4} Y_{t}^{2}+\beta_{5} O P P_{t} \\
+\varepsilon_{t} \cdots(3)
\end{gathered}
$$

$\mathrm{CO}_{2}=$ Environmental indicator which shows the per capita carbon dioxide emission in the country of Pakistan (metric kg per capita)

$\mathrm{Ec}=$ Per capita use of energy ( $\mathrm{kg}$ of oil equivalent per capita)

$\mathrm{Y}=$ Per capita growth as income (annual \%)

$\mathrm{Y}^{2}=$ per capita income square

Opp $=$ the trade openness (\% of GDP $)$.

$\mathrm{t}=$ Time period

The study also uses NOx (metric kg per capita) and $\mathrm{Mth}$ (metric $\mathrm{kg}$ equivalent to $\mathrm{CO}_{2}$ emission) as the environmental indicator which shows the per capita nitrogen oxide emission and per capita methane emission in the country of Pakistan. The explanatory variable $\mathrm{Y}$ expresses the per capita income (annual $\%)$. $\mathrm{Y}^{2}$ shows per capita real income square. Ec is showing the per capita use of energy (kilogram of oil equal to per capita) and in the last Opp is showing trade openness (\% of GDP). All the variables have been used with their logarithms, which mostly considered helpful for the reduction of heteroskedasticity. According to the model of study, the different values of coefficient of income could describe different functional forms. So we consider the different possible alternatives. Such as,
- $\mathrm{B}_{3}>0$ and $\beta_{4}=0$ explain the increasing relationship among income and pollution.

- $\mathrm{B}_{3}>0, \beta_{4}<0$ show reversed U-formed relationship.

- $\mathrm{B}_{3}<\mathrm{O}, \beta_{4}>0$ show an U-formed relation.

- $\mathrm{B}_{3}>\mathrm{O}, \beta_{4}<0$ and $\beta 5>0$ show the $\mathrm{N}$ formed relation among both variables.

\section{Estimation methodology}

Spurious regression may occur when the nonstationary form of sample time series data is placed. The latest procedure provided by Pesaran and Pesaran (1997), Pesaran (1997), Pesaran and Shin (1998), and Pesaran et al. (2001) has been placed in this literature. This method is referred to as an autoregressive distributed lag model (ARDL), and a particular modeling technique depends on the general approach. The ARDL has many benefits over other cointegration strategies. One of the main benefits of this method is that it can be applied regardless of whether the component is I(0), I(1)or co-integrated fractionally (Pesaran and Pesaran, 1997). The additional advantage of this approach is that the model requires a reasonable number of lags to confine the process of generating data to a particular modeling context in a dynamic system in general. Augmented Dickey-Fuller (ADF) test was used to render series stationery and eliminate the spurious regression problem.

ARDL method has some advantages like It allows the variables that they can utilize different optimal lag length, there is no issue if the order of integration of different variables is different like whether they are I (1), I (0) or mixed, also use for the small and large sample size of data and both long-run and short-run coefficient could be estimated by using ARDL method. In the ARDL process, bound testing is used to verify the relation between variables over the long run. F test and Wald test can be used to verify the relationship of the variables over the long run. When these are used as independent variables, the Serial Correlation LM test is used to verify the association between the variable and its lag. After that, the stability test is used to verify parameter stability which yields good results. To verify the course of a causal relationship, a causality test is applied.

\section{Data and Sources}

The yearly time series data has been used for the estimation of the model. Annual data were taken from the World Bank Indicator (WBI) online database for the year 1971 to 2011. The selection of the data was primarily based on data availability. The data about Pakistan was collected concerning all variables mentioned in the estimation model. Each variable has been used with their ordinary logarithms which 
generally considered to reduce Hetroskedasticity and Autocorrelation.

Study utilized the variable of trade openness as control variable. The data of trade openness was taken as \% of GDP. Trade openness is the aggregation of exports and imports of goods and services, taken as an estimation share from the gross domestic products of a country. This measure was used for assessing the globalization participation of a country. Data of the variable is taken from WDI data source.

\section{Results and Discussion}

The aim of this study was to observe the cointegration of environmental pollution elements and variable of economic growth for Pakistan in the longterm relationship. Generally the ARDL approach was used to evaluate the co-integration between the specified variables under consideration. Procedure implementation includes the following essential steps;

\section{Stationarity Analysis}

Stationarity is important analysis because if any series of variables become non-stationary then we can say that our results of classical regression with nonstationary series may not include any proper result and series also called "Spurious". The results of the ADF test are shown in table 1 . The null hypothesis of this study is the presence of unit root and stationary level proposed alternative hypothesis. As shown in table 1, $\mathrm{CO}_{2}, \mathrm{Y}, \mathrm{Y}^{2}$ and Opp are stationary at the level and Ec is stationary at the first difference under the sequence of null hypotheses is non-stationary.

\section{Lag Length Selection}

So after such results we can surely apply the ARDL approach according to Pesaran and Shin (1998), the SBC and AIC are mostly used for lag length selection criteria. SBC criteria also have choice to the other criteria because they tend to explain more parsimonious specification.

In this process the software automatically run the number of models and select optimal lag length model. $\mathrm{CO}_{2}$ selected by 2 lags. Energy consumption selected by 3 lags, per capita income by 2 lags, Per capita income square has 0 lags and trade openness has selected by the lag length of 3 lags.

\section{Table 1: Unit Root Testing}

\begin{tabular}{ccccc}
\hline Variables & Level & P-value & 1st difference & P- Value \\
\hline $\mathrm{CO}_{2}$ & -4.807744 & 0.0023 & & 0.004 \\
$\mathrm{Ec}$ & -0.277122 & 0.9887 & -5.439653 & \\
$\mathrm{Y}$ & -5.081543 & 0.0002 & \\
$\mathrm{Y}^{2}$ & -5.056278 & 0.0002 & \\
Opp & -4.859263 & 0.0003 & \\
\hline
\end{tabular}

Source: Author`s calculations

The results of model where it shows the long run coefficients are given in table 2. According to the signs of coefficients it can easy to define the relation between $\mathrm{CO}_{2}$ and effect of independent variables. The use of energy produces positive relationship with $\mathrm{CO}_{2}$.
Per capita income $\mathrm{Y}$ also has positive relation with dependent variable $\mathrm{CO}_{2}$. To observe the other side trade openness produces negative relationship with $\mathrm{CO}_{2}$.

Table 2: Long Run Estimates

\begin{tabular}{ccccc}
\hline Variable & Coefficient & Std. Error & t-Statistic & Prob. \\
\hline $\mathrm{C}$ & -6.540221 & 0.264127 & -24.761616 & 0.0000 \\
$\mathrm{EC}$ & 2.831026 & 0.115586 & 24.492825 & 0.0000 \\
$\mathrm{Y}$ & 0.039875 & 0.012555 & 3.175946 & 0.0042 \\
$\mathrm{Y}^{2}$ & -0.001968 & 0.001672 & -1.176809 & 0.2513 \\
$\mathrm{OPP}$ & -0.005523 & 0.003496 & -1.579929 & 0.1278 \\
$\mathrm{ECT}$ & -0.345686 & 0.060085 & -5.753250 & 0.0000 \\
\hline \multicolumn{2}{c}{$A R D L$ Co-integration and long run form, regressand variable: CO $\mathrm{O}_{2}$, Model: $A R D L(2,3,2,0,3)$}
\end{tabular}


The positive sign of energy consumption explained that it must be found positive relationship among use of energy and $\mathrm{CO}_{2}$ emission, mean to say $1 \%$ change in energy consumption will leads toward $2.831026 \%$ increasing change in $\mathrm{CO}_{2}$ emission. So it can be concluded that energy consumption is the main factor in Pakistan to increase the level of $\mathrm{CO}_{2}$ emission.

The positive sign of per capita income $\mathrm{Y}$ expressed that it must be found positive relationship among the variables of $\mathrm{CO}_{2}$ and income growth, mean to say that $1 \%$ change in $\mathrm{Y}$ will results the 0.039875 $\%$ increasing change in $\mathrm{CO}_{2}$ emission. The negative sign of Per capita income square $\mathrm{Y}^{2}$ expressed that it must be found negative relationship among the variables of $\mathrm{CO}_{2}$ and income growth, mean to say that $1 \%$ change in $\mathrm{Y}^{2}$ will results the $0.001968 \%$ decreasing change in $\mathrm{CO}_{2}$ emission. Trade openness also has negative relation with economic growth. By increasing $1 \%$ change in trade openness leads $0.005523 \%$ decreasing change in $\mathrm{CO}_{2}$ emission.

\section{Serial Correlation}

According to the above results now proceeds the diagnostic test which used to indicate the serial correlation between the variables. By serial correlation applying serial correlation LM test we conclude that the value of probability chi-square (2) is 0.3811 so we found that there is no indication for serial correlation among the given variables.

\section{Bound Testing}

The use of bound F-test for co-integration describes the indication of a long-term relationship between per capita $\mathrm{CO} 2$ emissions, per capita usage of electricity, trade accessibility and income growth at a level of 1 percent of Pakistan's significance. The bound test value is given in table 3 below. The findings revealed that there is a long-term correlation between the $\mathrm{CO} 2$ emission variables and the explanatory variables. Because the F-statistics value is greater than the Pesaran requirements value of the upper limit.

Table 3: Critical Value Bounds

\begin{tabular}{ccc}
\hline Significance & I0 Bound & I1 Bound \\
\hline $5 \%$ & 2.56 & 3.49 \\
$2.5 \%$ & 2.88 & 3.87 \\
$1 \%$ & 3.29 & 4.37 \\
\hline & F-Statistics > Upper Bound Value (5.528365 >4.37)
\end{tabular}

According to the result we reject our null hypothesis i-e all variables are zero, and accept the alternative hypothesis. It indicates that our all variable are not jointly zero and all variables have long run association.

\section{Stability Testing}

Brown et al, (1975) presented the CUSUM and CUSUMQ test to judge the stability of coefficients. Figure 1 and 2 presented CUSUM and CUSUMQ test graph respectively, which fall inner side of the criteria bounds at 5\% significance. The result of graph indicated that the calculated estimates are being unchanging over the given time span.

\section{Error Correction Model}

To check the short run and long run causality among the variables with the help of error-correction based on Wald testing. The coefficient of estimated significant at $1 \%$ confidence interval. The value of ETC is -0.345686 has the probability of 0.0000 which means that the whole system can get back to equilibrium with the speed of $34 \%$.

\section{Short Run Causality}

Causality is used to describe the cause and effect of dependent and independent variables in the model, which variable becomes the cause and which will be affected. For this purpose, the granger causality test can be applied. The null hypothesis of this test is there is no chance of granger causality between two variables. An alternative is one variable has a granger cause to other. It can be interpreted on the p-value of F-statistics. If the p-value of $F$ statistics is significant at a 5\% level of confidence interval it will reject the null hypothesis. That is no short-run causality among variables.

Ho $=$ There is no granger causality

$\mathrm{H} 1=$ There is granger causality

The result of the model also showed the causal relationship between the different variables given in table 4 which are summarized as given below;

i) There is an indication of a uni-directional shortrun causal relation between energy use and $\mathrm{CO}_{2}$ emission. Energy is the elementary source of $\mathrm{CO}_{2}$ emission.

ii) There is an indication of uni-directional shortrun causality between per capita $\mathrm{CO}_{2}$ emission 
and per capita income. Income growth is the primary source of $\mathrm{CO}_{2}$ emission.

iii) There is evidence of uni-directional short-run causality between per capita $\mathrm{CO}_{2}$ emission and a square of per capita income $\mathrm{Y}^{2}$. Income growth $\mathrm{Y}^{2}$ is the main cause of $\mathrm{CO}_{2}$ emission. iv) It is not found the short-run causality between the variables of trade openness and $\mathrm{CO}_{2}$ emission. Trade openness is not the main cause of $\mathrm{CO}_{2}$ emission in the country of Pakistan.

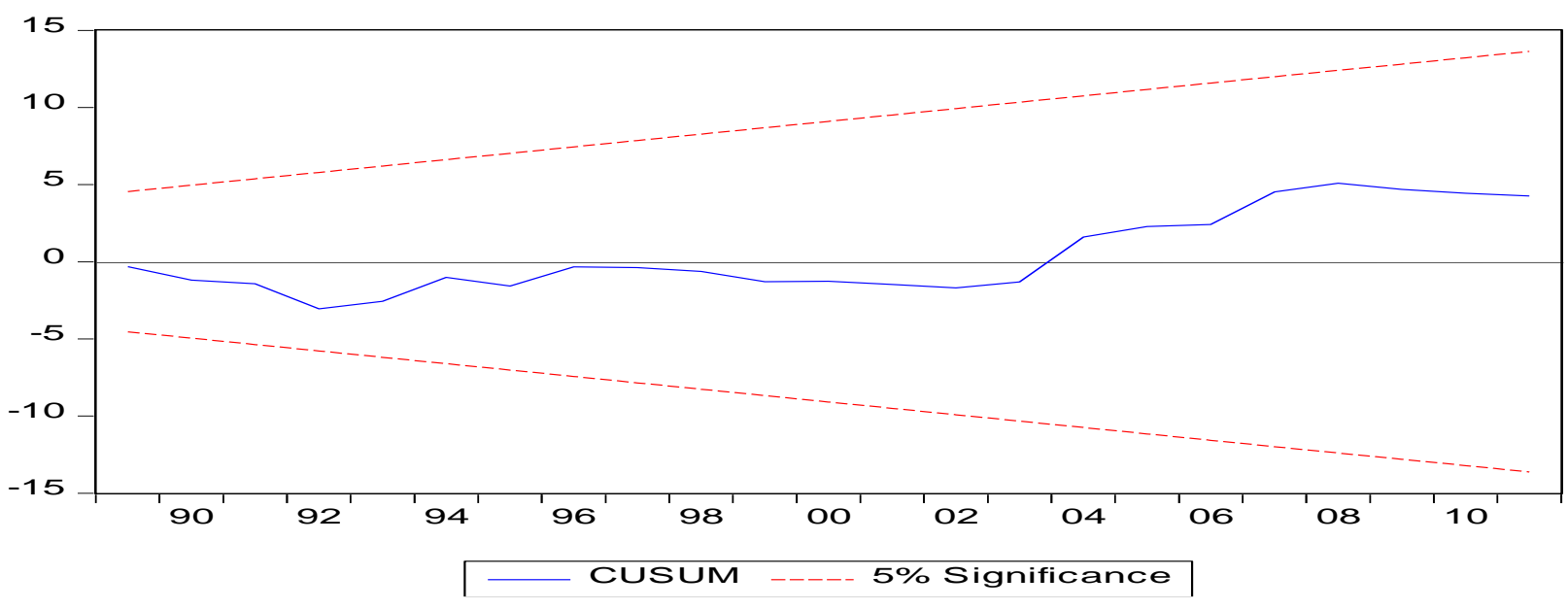

Figure 1: To Check Stability by CUSUM Test

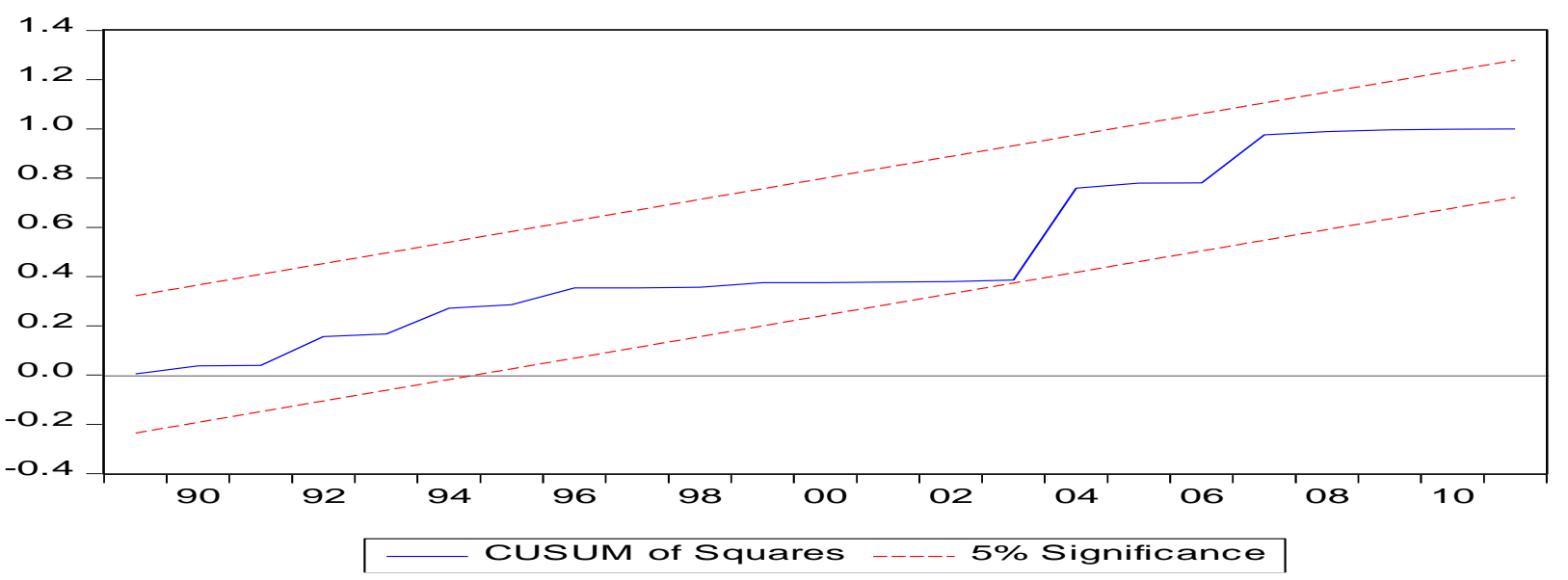

Figure 2: To Check Stability by CUSUMSQ Test

Table 4: Pairwise Granger Causality Test

\begin{tabular}{lll}
\hline Null Hypothesis & F-Statistics & P-value $(\boldsymbol{\alpha - 5 \% )}$ \\
\hline Ec does not granger cause of $\mathrm{CO}_{2}$ & 6.43099 & 0.0043 \\
$\mathrm{CO}_{2}$ does not granger cause of Ec & 0.96980 & 0.3894 \\
$\mathrm{Y}$ does not granger cause of $\mathrm{CO}_{2}$ & 7.50266 & 0.0020 \\
$\mathrm{CO}_{2}$ does not granger cause of $\mathrm{Y}$ & 1.55964 & 0.2249 \\
$\mathrm{Y}^{2}$ does not granger cause of $\mathrm{CO}_{2}$ & 4.34744 & 0.0208 \\
$\mathrm{CO}_{2}$ does not granger cause of $\mathrm{Y}^{2}$ & 0.53688 & 0.5893 \\
$\mathrm{Opp}^{2}$ does not granger cause of $\mathrm{CO}_{2}$ & 0.73473 & 0.4871 \\
$\mathrm{CO}_{2}$ does not granger cause of Opp & 0.90186 & 0.4153 \\
\hline
\end{tabular}

Source: Author's calculations

\section{Evidence of EKC in Pakistan}

The estimation of the model also represents the presence of environmental Kuznets bend in Pakistan. According to the results provided in table 5 the numerical sign of per capita income $\mathrm{Y}$ is positive but it is found that the Per capita income square has a negative sign. So the results explain that there is found 
a positive and significant relationship between per capita income and $\mathrm{CO}_{2}$ emission. Initially, the increase of income level the $\mathrm{CO}_{2}$ emission is going to increase but the negative sign of per capita income square is the evidence of turning point in the curve. Now there is the surety of negative economic relationship between the square of per capita income $\mathrm{Y}^{2}$ and $\mathrm{CO}_{2}$ emission. So the negative sign of $\mathrm{Y}^{2}$ will change the curve towards the downward direction after the turning point. The results of the study concluded that there is proof of reversed $U$ formed an environmental Kuznets curve in Pakistan.

Table 5: Long Run Estimates for Income Per Capita

\begin{tabular}{ccc}
\hline Regressors & Coefficients & P- values \\
\hline $\mathrm{Y}$ & 0.039875 & 0.0042 \\
$\mathrm{Y}^{2}$ & -0.001968 & 0.2513 \\
\hline
\end{tabular}

Source: Author's calculations

TABLE 6: Long Run Estimates for NOx

\begin{tabular}{ccc}
\hline Regressors & Coefficients & P- values \\
\hline Ec & 0.825426 & 0.0003 \\
Y & -0.048488 & 0.2742 \\
$\mathrm{Y}^{2}$ & 0.010065 & 0.2441 \\
Opp & -0.000786 & 0.0002 \\
\hline
\end{tabular}

Source: Author's calculations

Table 7: Long Run Estimates for Methane (Mth)

\begin{tabular}{ccc}
\hline Regressors & Coefficients & P-values \\
\hline Ec & 2.943333 & 0.0000 \\
Y & -0.008426 & 0.7534 \\
Y $^{2}$ & 0.004925 & 0.3583 \\
Opp & -0.023884 & 0.0669 \\
\hline
\end{tabular}

Source: Author's calculations

The study's results show that it is easy to draw the graph between different variables which can provide a clear view of the interpretation of results. This study utilizes the different pollutants as the dependent variable like $\mathrm{CO}_{2}$ emission, methane emission and nitrogen oxide NOx. The results describe that in Pakistan reversed $\mathrm{U}$ formed environmental Kuznets bend has been proved due to the relation between $\mathrm{CO}_{2}$ emission and income per capita, but there is no proof of reversed $\mathrm{U}$ formed environmental Kuznets bend during the relation between other pollutants like methane and NOx emission. The long-run estimates of other pollutants are given in table 6 .

The result of the other pollutants given in table 7 described the existence of $\mathrm{U}$ formed $\mathrm{EKC}$ in the country of Pakistan. The pollutants like $\mathrm{CO}_{2}$ with relation to independent variables are also shown in the graphical form. In figure 3 there are positive relationships describes that the increase in energy usage causes the level of $\mathrm{CO}_{2}$ to rise. 


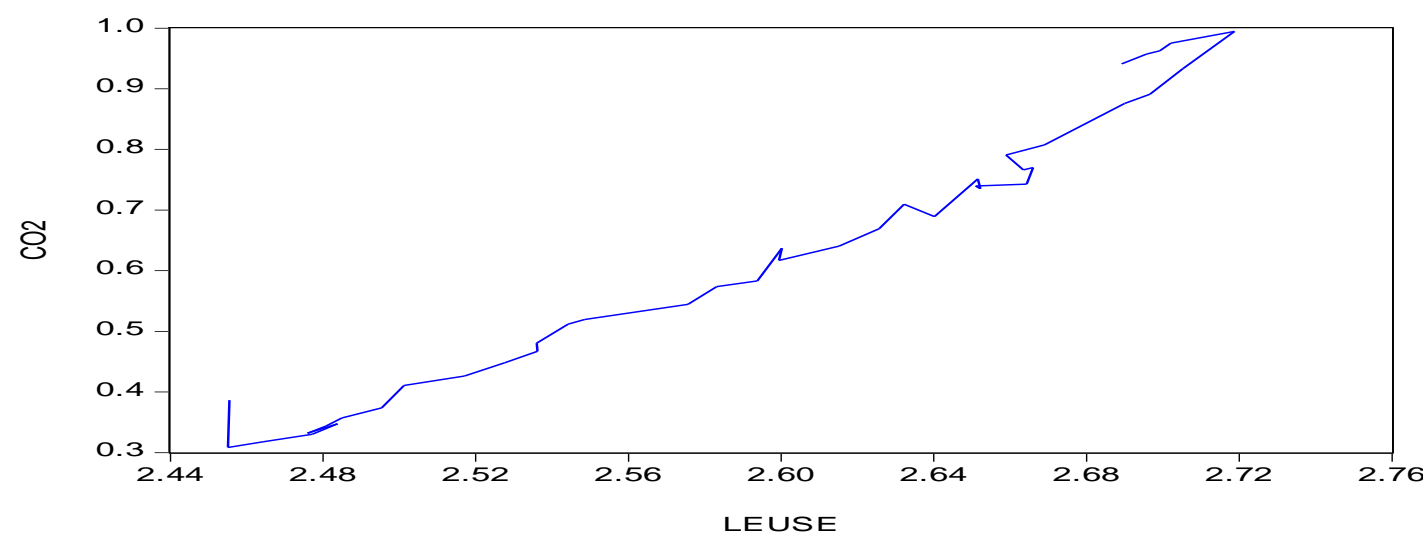

Figure 3: Relationship between Emission and Energy Use

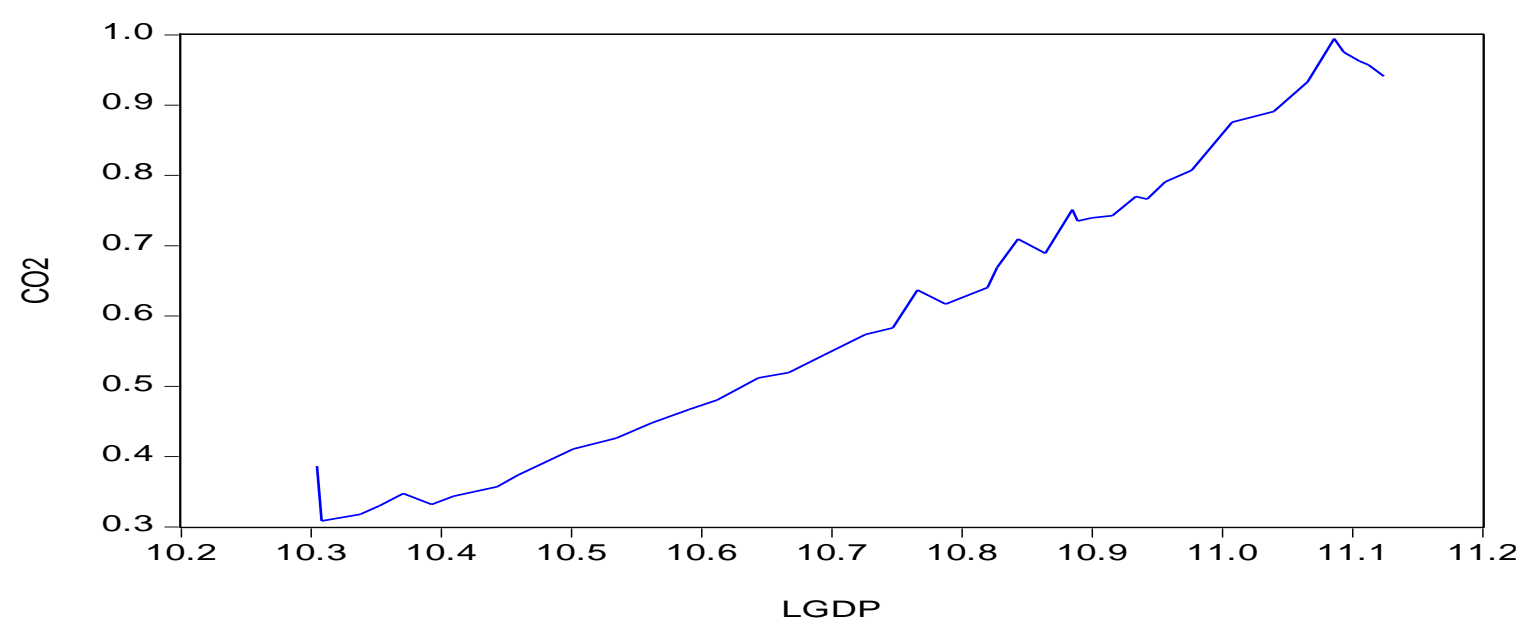

Figure 4: Relationship between $\mathrm{CO}_{2}$ and $\mathrm{PC}$ Income

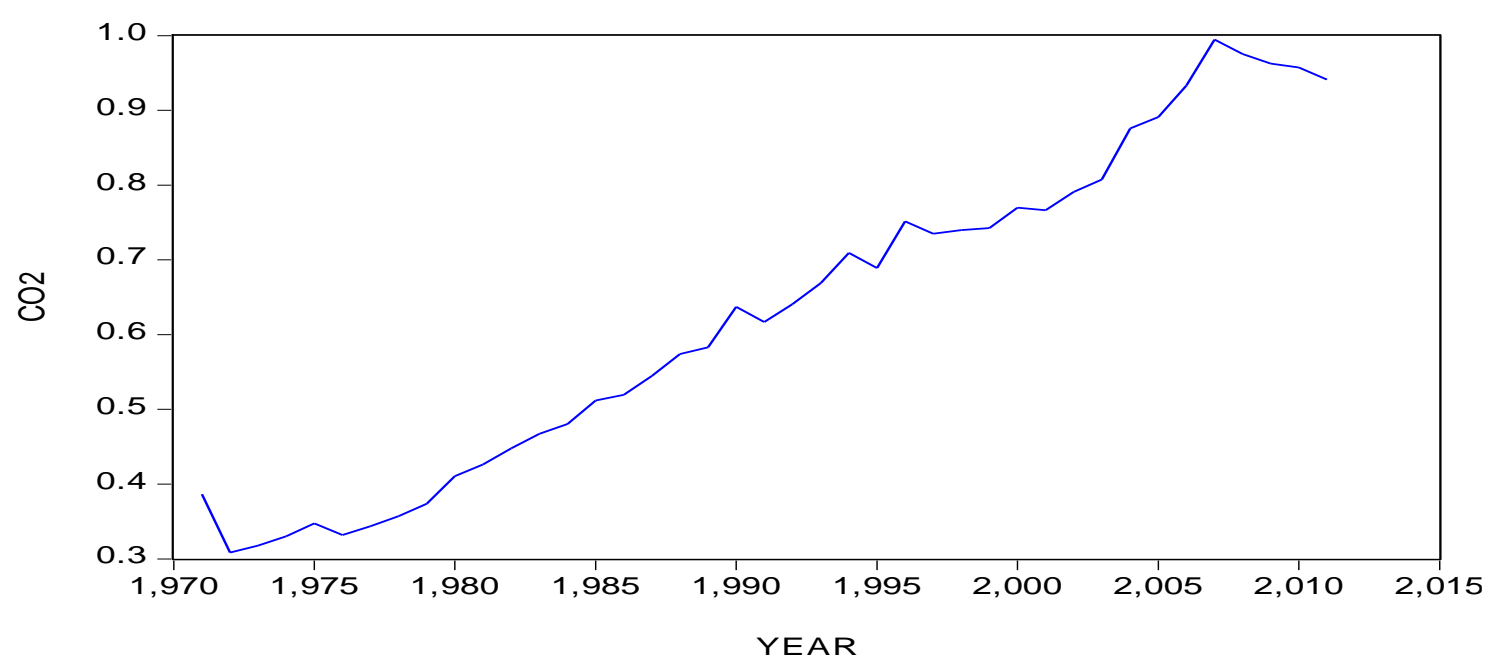

Figure 5: Relationship between $\mathrm{CO}_{2}$ Emission and Years

The energy use produces environmental degradation. In figure 4 it has been cleared that with the rise of per capita real income the quantity of $\mathrm{CO}_{2}$ also proliferations. Though per capita real income also producing environmental degradation. Figure 5 indicated that the quantity of $\mathrm{CO}_{2}$ increases over time and it has a positive trend. The EKC theory is not properly proved in China, the relationship among the quality of environment and income is different in the different forms of pollutants and areas. According to Wang et al. (2012) the reversed U-formed curve cannot be generalized for all elements of emissions. 


\section{Conclusions}

The results of the model conclude that energy use and per capita income growth has a positive relationship with $\mathrm{CO}_{2}$ emission. The results of the income variables are showing there is a presence of reversed $U$ formed environmental Kuznets bend in Pakistan. The per capita real income has a positive sign but the square of per capita real income has a negative sign which proves that after the turning point $\mathrm{CO}_{2}$ emission will decrease with the increase of income. The results of the study describe that there is the presence of reversed $\mathrm{U}$ formed environmental Kuznets bend in Pakistan due to the relation between $\mathrm{CO}_{2}$ emission and income growth, but there is no presence of reversed $U$ form environmental Kuznets

\section{References}

Akbostanc1, E., Türüt-Aşı1k, S., Tunç, G.İ., 2009. The relationship between income and environment in Turkey: is there an environmental Kuznets curve?. Energy policy, 37(3), 861-867.

Al-Mulali, U., Ozturk, I., 2015. The effect of energy consumption, urbanization, trade openness, industrial output, and the political stability on the environmental degradation in the MENA (Middle East and North African) region. Energy, 84, 382389.

Al-Mulali, U., Saboori, B., Ozturk, I., 2015. Investigating the environmental Kuznets curve hypothesis in Vietnam. Energy Policy, 76,123131.

Brown, R.L., Durbin, J., Evans, J.M., 1975. Techniques for testing the constancy of regression relationships over time. Journal of the Royal Statistical Society, Series B, 149-162.

Burke, P., 2008. Environmental Economics Research Hub Research Reports, ISSN 1835-9728.

EPA., 2013. Environment Protection Agency, Retrieved:

https://www.epa.ie/newsandevents/news/2013/

Everett, T., Ishwaran, M., Ansaloni, G.P., Rubin, A., 2010. Economic Growth and the Environment. In Defra Evidence and Analysis; Series Paper 2; Department for Environment Food and Rural Affairs: London, UK.

Field, C.B., Barros, V., Stocker, T.F. Dahe, Q. eds., 2012. Managing the risks of extreme events and disasters to advance climate change adaptation: special report of the intergovernmental panel on climate change. Cambridge University Press.

Ghafoor, A., Qadir, M., Murtaza, G., 2002. Agriculture in the Indus Plains: Sustainability of land and water resources. International Journal of Agriculture \& Biology, 4(3), 429-437. bend during the relation between other pollutants like methane and NOx emission. The relation between $\mathrm{CO}_{2}$ and per capita income $\mathrm{Y}$ is positive, which has strong evidence of reversed $U$ form environmental Kuznets curve in Pakistan. For the improvement and control of environment quality, energy sources should be carbon-free. The government should be imposed on taxes on carbon dioxide $\left(\mathrm{CO}_{2}\right)$ emissions. The government should introduce and create awareness about carbon capture, sequestration approaches, and technologies that can capture and store $\mathrm{CO}_{2}$ rather than to be present in the atmosphere. The government should spend the budget on green belt around the industrial areas and the vehicles which produce the black carbon emission in the atmosphere.

Groot, R., Wilson, M., Boumans, R., 2002. A Typology for the Classification Description and Valuation of Ecosystem Functions, Goods and Services, Vol - 41, 10.1016/S09218009(02)00089-7, Ecology Economics.

Harris, J. M., Roach, B., 2008. The economics of global climate change. Global Development and Environment Institute Tufts University.

Hung, M. F., Shaw, D., 2004. Economic Growth and the Environmental Kuznets Curve in Taiwan: A Simultaneity Model Analysis. Human Capital, Trade, and Public Policy in Rapidly Growing Economies: From Theory to Empirics, 269.

Jalil, A., Mahmud, S.F., 2009. Environment Kuznets curve for $\mathrm{CO} 2$ emissions: a cointegration analysis for China. Energy Policy, 37(12), 5167-5172.

Jobert, T., Karanfil, F., Tykhonenko, A., 2012. Environmental Kuznets Curve for carbon dioxide emissions: lack of robustness to heterogeneity? Galatasaray University Economic Research Center: 'Istanbul, Turkey.

Ozturk, I., Acaravci, A., 2013. The long-run and causal analysis of energy, growth, openness and financial development on carbon emissions in Turkey. Energy Economics, 36, 262-267.

Pao, H.T., Tsai, C.M., 2010. CO2 Emissions, energy consumption and economic growth in BRIC countries. Energy Policy, 38(12), 7850-7860.

Pesaran, M.H., 1997. The Role of Economic Theory in Modelling the Long Run, The Economic Journal, 107, 178-191.

Pesaran, M.H., Pesaran, B., 1997. Microfit 4.0 Interactive Econometric Analysis (Oxford University Press, Oxford.

Pesaran, M.H., Shin, Y., 1998. Generalized Impulse Response Analysis in Linear Multivariate Models. Economics Letters, 58 (1), 17-29.

Pesaran, M.H., Shin, Y., Smith, R. J., 2001. Bounds Testing Approaches to the Analysis of Level 
Relationship, Journal of Applied Econometrics, $16,289-326$.

Selden, T.M., Song, D., 1994. Environmental quality and development: is there a Kuznets curve for air pollution emissions? Journal of Environmental Economics and management, 27(2), 147-162.

Shahbaz, M., Mutascu, M. and Azim, P., 2013. Environmental Kuznets curve in Romania and the role of energy consumption," Renewable and Sustainable Energy Reviews, Elsevier, 8, 165-173.

Sharif, A., Raza, S.A., 2016. Dynamic Relationship between Urbanization, Energy Consumption and Environmental Degradation in Pakistan: Evidence from Structure Break Testing, Journal of Management Sciences, 3(1), 01-21.

Shen, J., 2006. A Simultaneous Estimation of Environmental Kuznets Curve: Evidence from China. China Economic Review, 17, 383-394.
Stern, D.I., 2004. The rise and fall of the environmental Kuznets curve. World development, 32(8), 1419-1439.

Tamazian, A., Chousa, J.P., Vadlamannati, K.C., 2009. Does higher economic and financial development lead to environmental degradation: evidence from BRIC countries. Energy policy, 37(1), 246-253.

Wang, Z., Yin, F., Zhang, Y., Zhang, X., 2012. An empirical research on the influencing factors of regional CO 2 emissions: evidence from Beijing city, China. Applied Energy, 100, 277-284.

Yang, L., Yuan, S., Sun, L., 2012. The relationships between economic growth and environmental pollution based on time series data: an empirical study of Zhejiang province. J Cambridge Stud, 7(1), 33-42. 